\title{
Planktonic Bacterial Population Dynamics with Environmental Changes in Coastal Areas of Suruga Bay
}

\author{
TAKAYUKi TAKENAKA ${ }^{1}$, TOMOKAZU TASHIRO ${ }^{2}$, AYUMI OZAKI $^{3}$, HitOMI TAKAKUBO $^{3}$, YUTAKA YAMAMOTO $^{3}$, \\ TOMOKO MARUYAMA ${ }^{3}$, KAZUYO NAGAOSA ${ }^{3}$, HIROYUKI KIMURA ${ }^{3}$, and KENJI KATO ${ }^{3 *}$ \\ ${ }^{1}$ Department of Biology and Geosciences, Graduate School of Science and Engineering, Shizuoka University, \\ 836 Ohya, Suruga-ku, Shizuoka 422-8529, Japan \\ 2 Department of Geosciences, Graduate School of Science, Shizuoka University, 836 Ohya, Suruga-ku, Shizuoka \\ 422-8529, Japan \\ ${ }^{3}$ Department of Geosciences, Faculty of Science, Shizuoka University, 836 Ohya, Suruga-ku, Shizuoka 422-8529, \\ Japan
}

(Received March 9, 2007-Accepted May 30, 2007)

We studied planktonic bacterial population dynamics in response to the changing environment in a coastal system during an observation period of over 5 years using fluorescence in situ hybridization. To estimate the environmental constraint on the bacterial community, we focused on temperature, salinity, abundance of photoplankton (chlorophyll $a$ ), and dissolved organic carbon (DOC). The total number of bacteria (TDC) amounted to $3.0 \times 10^{5}$ to $5.0 \times 10^{6}$ cells $\mathrm{mL}^{-1}$, with $1.0 \times 10^{5}$ to $1.0 \times 10^{6}$ cells $\mathrm{mL}^{-1}$ for Bacteria, accounting for 11.8 to $74.8 \%$ of TDC, and $1.0 \times 10^{4}$ to $1.0 \times 10^{5}$ cells $\mathrm{mL}^{-1}$ for Gammaproteobacteria, 1.0 to $20.8 \%$ of TDC. The abundance of Archaea, which contributed from 0.1 to $12 \%$ to TDC, ranged from $2.0 \times 10^{3}$ to $3.0 \times 10^{4}$ cells $\mathrm{mL}^{-1}$. We found a positive relationship between environmental parameters such as temperature, salinity, chlorophyll $a$, and DOC and the abundance of total bacteria and Bacteria. The number of Gammaproteobacteria correlated with temperature, salinity, and chlorophyll $a$, but not with DOC. We suggest that increasing the temperature under eutrophic conditions will lead to high bacterial abundance and probably a change in the bacterial community.

Key words: temperature, salinity, Gammaproteobacteria, fluorescence in situ hybridization, coastal environment

Molecular analyses of natural bacterial assemblages have provided a knowledge of bacterial community structure directly and precisely without cultivation bias. Bacterial diversity in various environments and the predominance of a certain bacterial population in a certain marine milieu was shown by gene analysis ${ }^{5)}$. One preceding study revealed a difference in bacterial community constituents between attached aggregates and free-living bacterial assemblages ${ }^{7)}$. Other findings, such as the abundance of Alphaproteobacteria in estuarine and coastal environments ${ }^{13)}$ and the existence of Archaea in coastal waters ${ }^{23)}$, have been revealed by the molecular analysis of prokaryotic microbial communities. The environmental control of bacterial assemblages ${ }^{4,25)}$

\footnotetext{
* Corresponding author. E-mail address: skkato@ipc.shizuoka. ac.jp; Tel.: +81-54-238-4950; Fax: +81-54-238-4950.
}

and the relationship between the aquatic environment and the distribution of functional bacterial groups ${ }^{5,19)}$ were also shown by molecular analyses of bacterial communities ${ }^{15,18)}$. Among the methods of molecular analysis, the fluorescence in situ hybridization (FISH) technique, developed by DeLong et al. ${ }^{6}$, provides quantitative information about bacterial community structure and the abundance of individual organisms in populations. Direct quantitative comparisons of bacterial community structures have thus become possible ${ }^{12}$. Population shifts in response to environmental changes, such as nutrient enrichment, have also been revealed by this technique ${ }^{8)}$. In a coastal environment, a trend in the distribution of individual bacterial groups was explained by salinity in a study in which FISH was used with probes to identify Alphaproteobacteria, Betaproteobacteria, and Cytophaga-like groups ${ }^{17)}$. We investigated the 
environmental regulation of bacterial abundance, focusing particularly on temperature, salinity, abundance of phytoplankton (chlorophyll $a$ ), and dissolved organic carbon (DOC). To consider the influence of the flow of water into the estuary from the urban area, the Gammaproteobacterial population was chased as an indicator of the enterobacterial group $^{8,10,11,26)}$. The influence of the urban environment on marine microbial communities was considered in relation to salinity.

\section{Materials and Methods}

\section{Study site and sample collection}

Observation of the natural environment and water sampling were carried out from December 2001 to August 2005 at two sampling sites in Suruga Bay. Sampling was always carried out from 9:00 a.m. to 12:00. Site $1\left(35^{\circ} 00^{\prime} 56^{\prime \prime} \mathrm{N}\right.$, $138^{\circ} 30^{\prime} 58^{\prime \prime E}$ ) was inside Shimizu Port (Fig. 1), $1.5 \mathrm{~km}$ northeast of the estuary of Tomoe River which was 30-70 $\mathrm{m}$ in width and 1-2 $\mathrm{m}$ deep. It was expected that the environment of Site 1 would be affected by human activity in the surrounding urban area through the inflow of river water. Site $2\left(35^{\circ} 01^{\prime} 18^{\prime \prime} \mathrm{N}, 138^{\circ} 31^{\prime} 45^{\prime \prime} \mathrm{E}\right)$ was outside Shimizu Port and was located $1 \mathrm{~km}$ northeast of Site 1 (Fig. 1). This site may represent the coastal environment of Suruga Bay with less influence from urban activity.

Surface water at each site was expected to be affected directly by climate changes, such as sunshine and rainfall, whereas the water at a depth of $10 \mathrm{~m}$ was expected to be less influenced by these factors, except at times of a typhoon or storm. However, the water current beneath the surface might be complex in these coastal environments. Since the Secchi depth ranged from 3 to $4 \mathrm{~m}$, we supposed that pri- mary production was restricted to above about $8 \mathrm{~m}$ of the water body.

Water samples were collected from the surface and a depth of $10 \mathrm{~m}$ at both sites. The water at the surface was collected with a sterilized Pyrex bottle at each sampling site. The water at $10 \mathrm{~m}$ was collected with a 10-liter Niskin sampler (model 5026-D, Rigosha, Tokyo, Japan) and immediately subsampled into a sterilized Pyrex bottle for microbial analyses, measurement of chlorophyll $a$, and chemical analyses. All samples were transported to the laboratory on ice within a few hours of collection.

\section{Sample processing}

In the laboratory, a subsample was fixed with neutralized formaldehyde ( $\mathrm{pH} 7.4$, final concentration 5\%) for a total direct count of bacteria (TDC). A subsample for FISH analysis was fixed with paraformaldehyde $(\mathrm{pH} 7.4$, final concentration $3 \%$ ) and kept at $4{ }^{\circ} \mathrm{C}$ for up to $24 \mathrm{~h}$. The fixed sample was then filtered gently on a $0.2-\mu \mathrm{m}$ Nuclepore filter (25 mm diameter). Cells trapped on the filter were rinsed three times with PBS and dehydrated with $1 \mathrm{~mL}$ of 50,80 , and $100 \%$ ethanol for $3 \mathrm{~min}$ each, and the filter was airdried. Filters were stored at $-20^{\circ} \mathrm{C}$ until hybridization.

\section{Measurement of environmental parameters}

Water temperature, salinity, $\mathrm{pH}$, conductivity, and dissolved oxygen (DO) were measured at the site using a water quality checker (model U-10, Horiba, Tokyo, Japan) for surface samples and $10 \mathrm{~m}$ deep samples from Sites 1 and 2. Chlorophyll $a$ was measured by the UNESCO method ${ }^{28)}$. DOC was analyzed with a total organic carbon analyzer (TOC-5000, Shimadzu, Kyoto, Japan) for the samples collected between 6 August 2002 and 1 December 2004. For

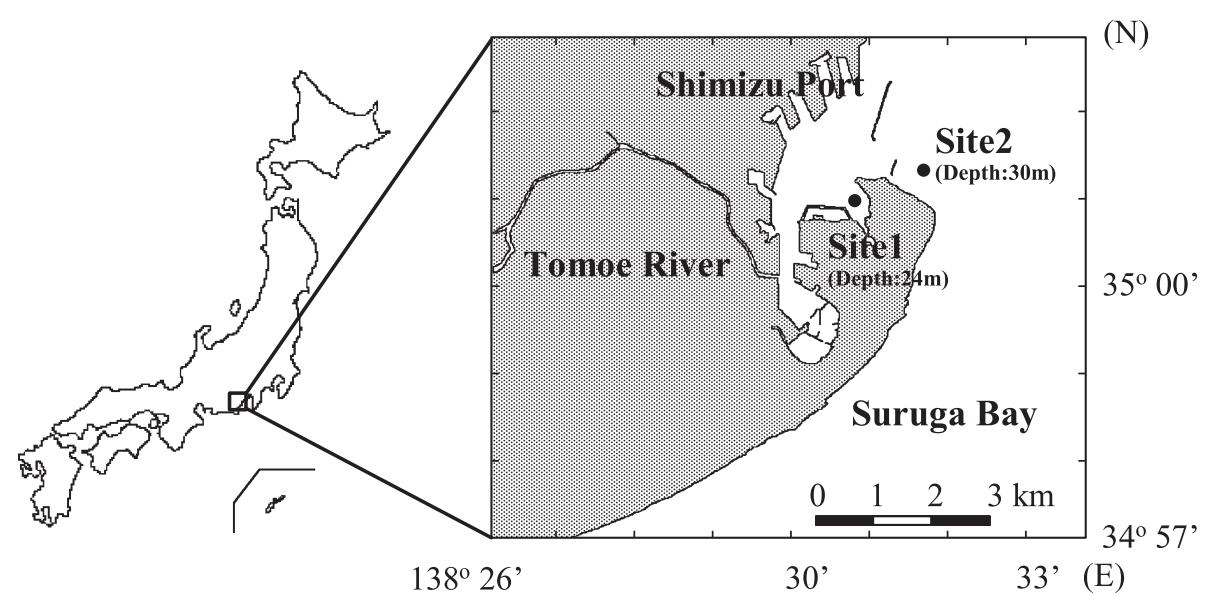

Fig. 1. Sampling site: Site $1\left(35^{\circ} 00^{\prime} 56^{\prime \prime} \mathrm{N}, 138^{\circ} 30^{\prime} 58^{\prime \prime} \mathrm{E}\right)$; Site $2\left(35^{\circ} 01^{\prime} 18^{\prime \prime N}, 138^{\circ} 31^{\prime} 45^{\prime \prime} \mathrm{E}\right)$. 
the samples collected on 15 April and 2 August 2005, DOC was analyzed with a total organic carbon analyzer (TOCVCSH, Shimadzu). Concentrations of nutrients $\left(\mathrm{NO}_{3}^{-}, \mathrm{NO}_{2}^{-}\right.$, $\mathrm{NH}_{4}{ }^{+}$, and $\mathrm{PO}_{4}{ }^{3-}$ ) were analyzed with a TRAACS 2000 analyzer (Bran+Luebbe, Norderstedt, Germany) for the samples collected between 6 August 2002 and 2 August 2005. Ammonia and phosphate concentrations were analyzed with the indophenol method ${ }^{29}$ and the molybdenum blue method ${ }^{22)}$, respectively, for the samples collected on 1 December 2001.

\section{Total direct bacterial count}

Fixed samples were stained with 4',6-diamidino-2-phenylindole (DAPI; final concentration, $\left.0.01 \mu \mathrm{g} \mathrm{mL}^{-1}\right)^{27)}$ and more than 1000 bacterial cells in 20 objective fields were counted by epifluorescence microscopy (BX50-FLA, Olympus, Tokyo, Japan).

\section{Whole-cell in situ hybridization}

The 16S rRNA-targeted oligonucleotide probes employed in this study are listed in Table 1. They comprised a domain-specific probe for Bacteria (EUB338) ${ }^{1)}$ and Archaea (ARCH915) ${ }^{30)}$, and probes specific for the phylogenetic group Gammaproteobacteria (GAM42a) ${ }^{20)}$. These probes were labeled with rhodamine (Nihon Bioservice, Saitama, Japan). In addition, we employed a non-labeled specific probe for Betaproteobacteria (BET42a) ${ }^{20)}$ as a competitor to GAM42a, because there was only one base pair mismatch between these probes.

As a negative control, we used NON338 32 and NONGAM (5'-TTT GCT ACA CCC TTC CG-3'), complementary to probes EUB338 and GAM42a, to confirm the accuracy of our FISH procedure for Bacteria and Gammaproteobacteria.

Hybridization stringency was adjusted by varying the concentration of formamide in the hybridization buffer and $\mathrm{NaCl}$ in the washing solution ${ }^{1,6)}$. Hybridizations were performed at $46^{\circ} \mathrm{C}$ for $90 \mathrm{~min}$ on filters placed on slides coated with gelatin, hybridization buffer containing $0.9 \mathrm{M} \mathrm{NaCl}$, $20 \mathrm{mM}$ Tris- $\mathrm{HCl}$ (pH 7.4), 0.01\% SDS, formamide $(20 \%$ for EUB338 and NON338, or $35 \%$ for ARCH915, GAM42a, and NON-GAM), and $5 \mathrm{ng} \mu \mathrm{L}^{-1}$ of the respective labeled probe. Each filter was washed at $48^{\circ} \mathrm{C}$ for $15 \mathrm{~min}$ in prewarmed washing buffer containing $\mathrm{NaCl}(0.225 \mathrm{M}$ for EUB338 and NON338, 0.070 M for ARCH915, and 0.080 $\mathrm{M}$ for GAM42a and NON-GAM), $20 \mathrm{mM}$ Tris-HCl (pH 7.4), $5 \mathrm{mM}$ EDTA, and $0.01 \%$ SDS, then rinsed with distilled water and air-dried. The preparations, which were counterstained with $0.1 \mu \mathrm{g} \mathrm{mL} \mathrm{mL}^{-1}$ DAPI on glass slides for 5 min, were observed under a universal epifluorescence microscopic system (BX50-FLA, Olympus) with a 3-CCD camera (model C5810, Hamamatsu Photonics, Shizuoka, Japan) and a digital camera (model DP-70, Olympus) with an image analysis system (SP500F and DP controller, Olympus).

\section{Statistical analysis}

We analyzed the relationship between bacterial numbers (TDC and the numbers of Bacteria, Archaea, and Gammaproteobacteria) and the environmental parameters using the Pearson product-moment correlation coefficient $(p<0.05$ or 0.01 ). Statistical analysis was performed with Microsoft Office Excel 2003 SP2.

\section{Results}

In situ observations and sampling for chemical and microbial analyses were carried out nine times between 1 December 2001 and 2 August 2005 at Sites 1 and 2 (Fig. 1). Environmental fluctuation throughout the observation period is summarized in Fig. 2.

\section{Environmental parameters}

Temperature (Fig. 2a)

The observed water temperature ranged from 12.5 to $28.9^{\circ} \mathrm{C}$, with no significant difference between the sites

Table 1. Probe sequences and target site

\begin{tabular}{lllcc}
\hline Probe name & \multicolumn{1}{c}{ Target organisms } & \multicolumn{1}{c}{ Sequence (5'-3') } & Target site* rRNA Position & Reference \\
\hline EUB338 & Bacteria & GCT GCC TCC CGT AGG AGT & $16 \mathrm{~S}, 338-355$ & 1 \\
BET42a & Betaproteobacteria & GCC TTC CCA CTT CGT TT & $23 S, 1027-1043$ & 20 \\
GAM42a & Gammaproteobacteria & GCC TTC CCA CAT CGT TT & $23 S, 1027-1043$ & 20 \\
ARCH915 & Archaea & GTG CTC CCC CGC CAA TTC CT & $16 S, 915-934$ & 30 \\
NON338 & negative control of EUB338 & ACT CCT ACG GGA GGC AGC & $16 S, 338-355$ & 32 \\
NON-GAM & negative control of GAM42a & TTT GCT ACA CCC TTC CG & 23S, 1027-1043 & this study \\
\hline
\end{tabular}

\footnotetext{
* Escherichia coli numbering ${ }^{3}$.
} 


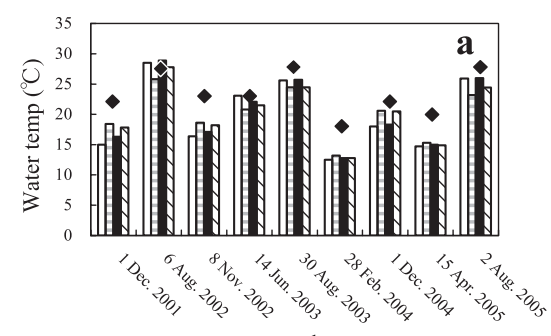

date
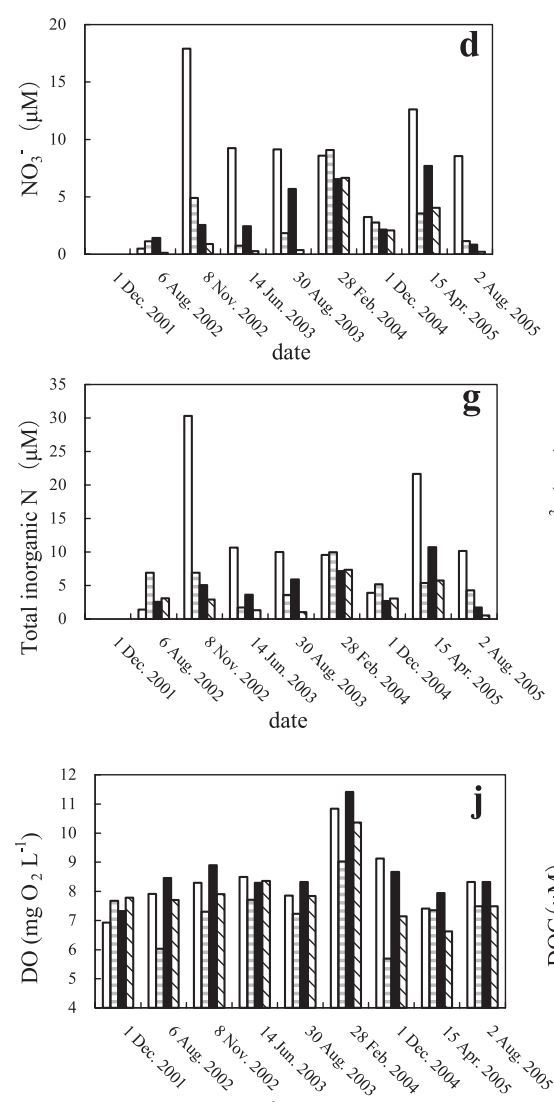

date

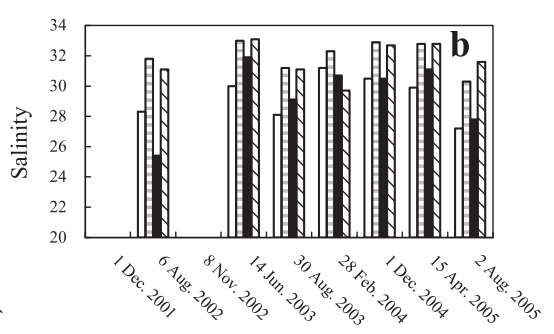

date
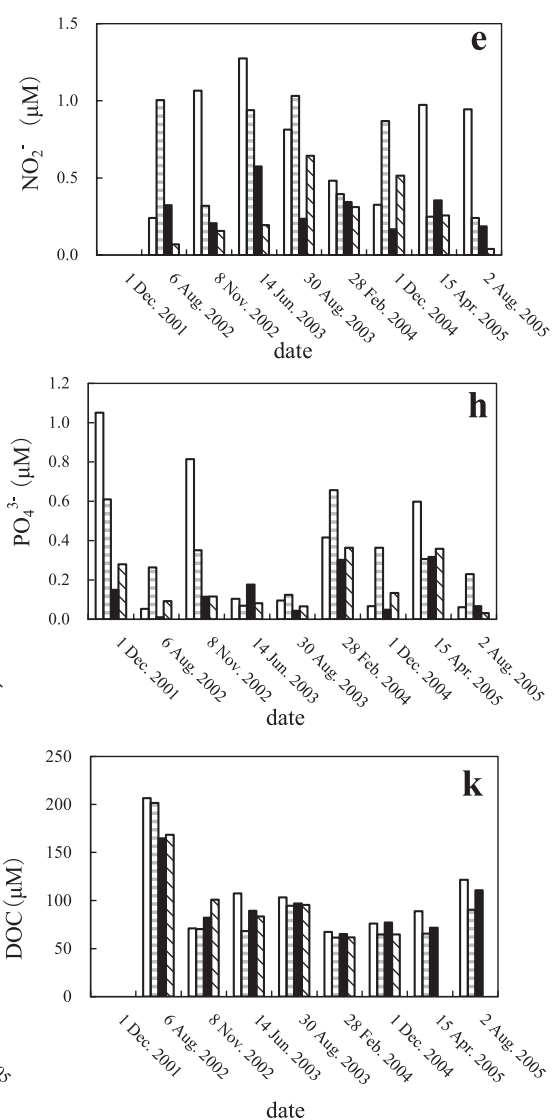

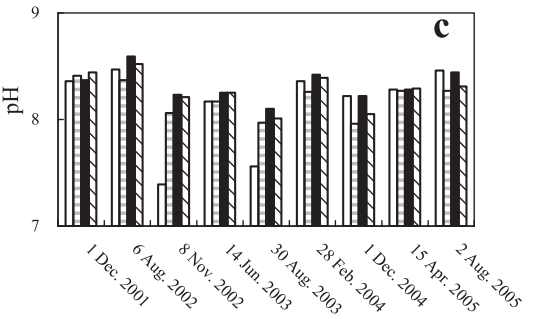

date
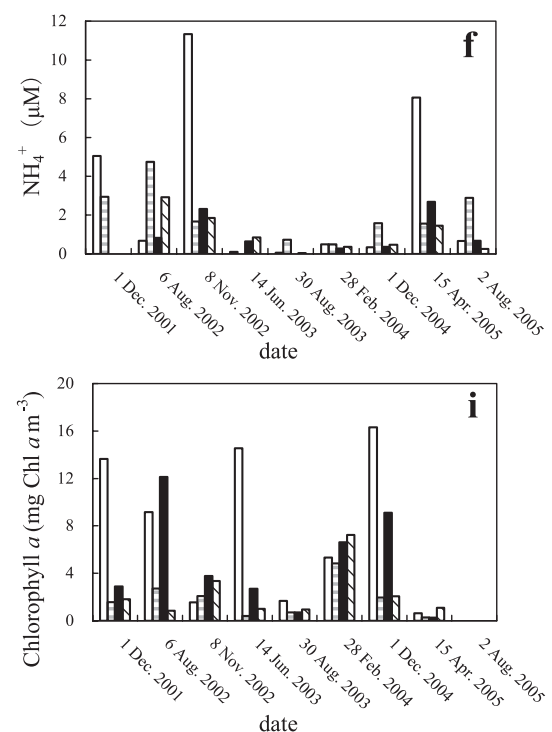

date

Fig. 2. Changes in environmental parameters. a, water temperature; b, salinity; $\mathbf{c}, \mathrm{pH} ; \mathbf{d}, \mathrm{NO}_{3}^{-} ; \mathbf{e}, \mathrm{NO}_{2}^{-} ; \mathbf{f}, \mathrm{NH}_{4}^{+} ; \mathbf{g}$, total inorganic $\mathrm{N}^{-} \mathbf{h}, \mathrm{PO}_{4}{ }^{3-}$; $\mathbf{i}$, chlorophyll $a$; j, DO; k, DOC; water temperature on sampling date ( $\square$ Site $1,0 \mathrm{~m} ; \Xi$ Site $1,10 \mathrm{~m} ; \mathbf{\square}$ Site $2,0 \mathrm{~m} ; \Delta \mathrm{Site} 2,10 \mathrm{~m}, \bullet$ Kuroshio Current, data were from Hydrographic and Oceanographic Department Japan Coast Guard, http://www1.kaiho.mlit.go.jp/).

inside and outside the port. Water temperature was relatively high at the surface in summer, and was high at a depth of $10 \mathrm{~m}$ in winter. The water temperature inside and outside Shimizu port related with that measured in the Kuroshio Current, which passes roughly $100-200 \mathrm{~km}$ from the shore, the difference being approximately $0.2-8.0^{\circ} \mathrm{C}$.

\section{Salinity (Fig. 2b)}

Salinity fluctuated greatly at the surface both inside and outside the port irrespective of season, ranging from 25.4 to 31.2 , whereas at $10 \mathrm{~m}$ deep, it fluctuated within a relatively small range, from 29.7 to 33.0. Except for the unusually low salinity observed on 6 August 2002 at the surface at Site 2, the pattern of fluctuation in salinity was similar inside and outside the port. This, together with the high salinity values obtained, indicates that the deep water was not strongly affected by the freshwater supply from the river, even inside the port.

\section{pH (Fig. 2c)}

The $\mathrm{pH}$ values observed did not fluctuate greatly except for the surface water at Site 1 . The median $\mathrm{pH}$ value was 
over 8.0, although low values were measured at the surface at Site 1 on 8 November 2002 and 30 August 2003.

\section{$\mathrm{NO}_{3}^{-}$(Fig. 2d)}

High concentrations of $\mathrm{NO}_{3}{ }^{-}$were observed at the surface at Site 1 , ranging mostly from 0.49 to $17.91 \mu \mathrm{M}$. At the three other sampling points, the concentration of $\mathrm{NO}_{3}{ }^{-}$was below $10 \mu \mathrm{M}$. The highest concentration of $\mathrm{NO}_{3}{ }^{-}$was measured at the surface inside the bay on 8 November 2002 . However, no significant relation was found between $\mathrm{NO}_{3}^{-}$ and chlorophyll $a$, as was also true for other nutrients (data not shown).

\section{$\mathrm{NO}_{2}^{-}$(Fig. 2e)}

Values were not high, ranging between 0.17 and 1.27 $\mu \mathrm{M}$. However, there was a tendency for $\mathrm{NO}_{2}{ }^{-}$concentrations to be higher at Site 1 than at Site 2. The highest concentration was observed in surface water at Site 1 on 14 June 2003.

\section{$\mathrm{NH}_{4}^{+}$(Fig. 2f)}

High concentrations of $\mathrm{NH}_{4}{ }^{+}$were sometimes observed at the surface inside the port, where the range was from below the detection limit to $11.33 \mu \mathrm{M}$. The highest concentration was observed in the surface water inside the port on 8 November 2002. The $\mathrm{NH}_{4}{ }^{+}$concentration was low, ranging from below the detection limit to $1.58 \mu \mathrm{M}$, throughout from 14 June 2003 to 1 December 2004.

\section{Total inorganic $N$ (Fig. 2g)}

The total inorganic $\mathrm{N}$ concentration, the sum of $\mathrm{NO}_{3}^{-}$, $\mathrm{NO}_{2}^{-}$, and $\mathrm{NH}_{4}{ }^{+}$, was mostly high in the surface water at Site 1. The highest concentration was observed at the surface inside the port on 8 November 2002, when $\mathrm{pH}$ was significantly low suggesting a strong influence of inflowing water. The fluctuation of total inorganic $\mathrm{N}$ seemed to be governed by that of $\mathrm{NO}_{3}{ }^{-}$.

\section{$\mathrm{PO}_{4}{ }^{3-}$ (Fig. 2h)}

When the two observation sites were compared, a relatively high concentration of $\mathrm{PO}_{4}{ }^{3-}$ was found at Site 1 but the measured concentration was low, being $0.01-1.05 \mu \mathrm{M}$ throughout the observation period. The highest concentration was observed in the surface water at Site 1 on 1 December 2001. The concentration of $\mathrm{PO}_{4}{ }^{3-}$ showed a tendency to be high when water temperature was lower than $20^{\circ} \mathrm{C}$ (data not shown).

\section{Chlorophyll a (Fig. 2i)}

The chlorophyll $a$ concentration fluctuated widely at the surface, ranging from 0.27 to $16.31 \mathrm{mg} \mathrm{Chl.} a \mathrm{~m}^{-3}$, while at a depth of $10 \mathrm{~m}$ it ranged from 0.29 to $7.23 \mathrm{mg} \mathrm{Chl.} a \mathrm{~m}^{-3}$. High concentrations were found at the surface in winter as well as in summer. When we compared the concentration of chlorophyll $a$ between the surface and at $10 \mathrm{~m}$, higher concentrations were sometimes observed outside the port, as occurred on 28 February 2004, when relatively high values were observed at both sites.

\section{Dissolved oxygen (Fig. 2j)}

The DO concentration did not fluctuate widely, but relatively high values were observed in surface water. The concentration was highest on 28 February 2004 (9.03-11.42 mg $\mathrm{L}^{-1}$ ), which corresponded to the high chlorophyll $a$ concentration mentioned above.

\section{Dissolved organic carbon (Fig. 2k)}

Excepting the high concentrations measured on 6 August 2002 (164.7-206.6 $\mu \mathrm{M})$, samples showed relatively stable values, ranging between 61.7 and $121.5 \mu \mathrm{M}$. No significant relation between the concentrations of DOC and chlorophyll $a$, a major source of DOC, was found at the study sites.

\section{Characteristics of observation sites Horizontal comparison}

Compared with values outside the bay (Site 2), the concentrations of nutrients and chlorophyll $a$ inside the bay (Site 1) were high, especially at the surface, but salinity was low. Temperature, salinity, and the DO concentration showed similar patterns of fluctuation at the two sites.

\section{Vertical comparison}

Surface water showed considerable fluctuations in temperature and salinity, and high concentrations were found for nutrients, chlorophyll $a$, and DO. On the other hand, we observed less fluctuation in each parameter at a depth of 10 $\mathrm{m}$ than at the surface.

\section{Total direct count of bacteria}

TDC did not fluctuate markedly, with the range between $3.0 \times 10^{5}$ and $5.0 \times 10^{6}$ cells $\mathrm{mL}^{-1}$ throughout the observation period at all stations (Fig. 3), though in two of three cases in August (6 August 2002 and 2 August 2005), abundance was high (Fig. 4a). TDC at the surface tended to be higher than that at depth for both Sites 1 and 2. Figure 4a shows that 

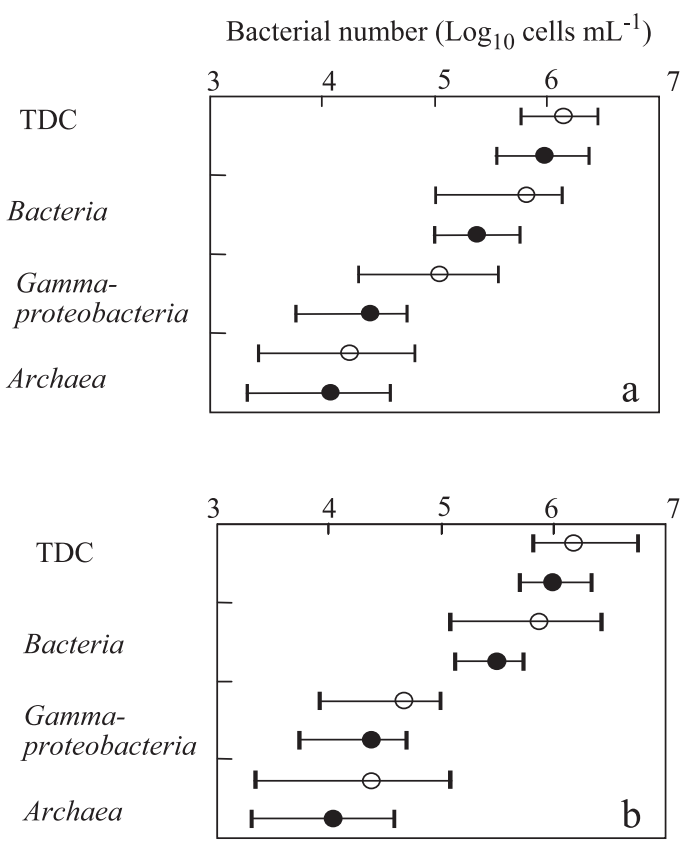

Fig. 3. Fluctuation range of abundance of bacteria. a, Site 1; b, Site

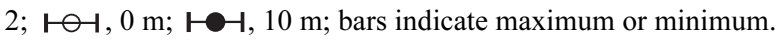

TDC at Site 1 generally exceeded that at Site 2.

\section{Percentage of cells hybridized with probes}

About $14.7-76.7 \%$ of all bacteria were hybridized with gene probes, targeted to Bacteria or Archaea (Fig. 4b). A high proportion of hybridization was found for samples from surface water at Site 2, with eight out of nine samples showing hybridization with more than $40 \%$ of TDC, compared to only two samples from $10 \mathrm{~m}$ deep at Site 2. At Site 1 , four of the surface samples showed hybridization with more than $40 \%$ of TDC, compared to only two samples at $10 \mathrm{~m}$. It is remarkable that bacteria sampled in summer did not necessarily show a high proportion of hybridization, and vice versa for winter samples. A high proportion of hybridization was found for surface water at Site 1 on 28 February 2004. In general, bacteria from surface samples showed a higher proportion of hybridization than samples taken at a depth of $10 \mathrm{~m}$ for both Sites 1 and 2 (Fig. 4b). A low proportion of hybridization was observed for all samples on 30 August 2003, which seemed to be related to a low phytoplankton biomass (Fig. 2i), though the reverse was not necessarily true as for the case of 15 April 2005.

\section{Bacteria}

The number of Bacteria ranged from $1.0 \times 10^{5}$ to $1.0 \times 10^{6}$ cells $\mathrm{mL}^{-1}$ throughout the observation period (Fig. 3). Bac- teria, identified by FISH, constituted $11.8-76.1 \%$ of TDC. The proportion of Bacteria in surface water was generally higher than that at a depth of $10 \mathrm{~m}$. At $10 \mathrm{~m}$, Site 2 showed a higher number of Bacteria than Site 1 (Fig. 4c).

A remarkably large number of Bacteria was found on 6 August 2002 in the surface water at Site $2\left(2.6 \times 10^{6}\right.$ cells $\mathrm{mL}^{-1}$ ) but the proportion with respect to TDC did not exceed $50 \%$.

The proportion of Bacteria to TDC was highest on 14 June 2003 except for surface water at Site 1. In the subsequent observation carried out on 30 August 2003, both the number of cells and the proportion of Bacteria to TDC were lowest, when a remarkably low chlorophyll $a$ concentration was observed even in the surface water at Site1 (Fig. 2i). It is worth noting that the percentage of the sum of Bacteria and Archaea in surface water at Site 2 exceeded that at Site 1 in five out of nine observations.

\section{Gammaproteobacteria}

The number of Gammaproteobacteria ranged from $1.0 \times 10^{4}$ to $1.0 \times 10^{5}$ cells $\mathrm{mL}^{-1}$ throughout the observation period for all stations. The number in surface water showed a tendency to be higher inside the port (Site 1) than at other sampling points (Fig. 3). The number reached ca. 3.0 $\times 10^{5}$ cells $\mathrm{mL}^{-1}$ in surface water at Site 1 on 1 December 2001 and 2 August 2005. The proportion of Gammaproteobacteria as a percentage of TDC detected by FISH ranged from 1.0 to $11.7 \%$, except in surface water at Site 1 on 1 December 2003, where it was $20.8 \%$. The proportion of Gammaproteobacteria as a percentage of Bacteria ranged from 1.9 to $30.4 \%$. The highest proportion was found on 30 August 2003, when the smallest proportion of Bacteria relative to TDC was observed (see above). The proportion of Gammaproteobacteria relative to TDC and also to Bacteria (data not shown) at the surface showed a tendency to be higher at Site 1 than at any other sampling points.

\section{Archaea}

The number of Archaea ranged between $2.0 \times 10^{3}$ and $3.0 \times 10^{4}$ cells $\mathrm{mL}^{-1}$, which was smaller than that of Bacteria by two orders of magnitude (Fig. 3). The number of Archaea was very low, but we detected Archaea in all samples examined. The proportion of Archaea to TDC detected by FISH ranged from 0.1 to $3.2 \%$ except for surface water at Site 2 on 1 December 2001, when Archaea constituted $12.0 \%$ of TDC. Archaea were present in greater abundance compared with all other samples on 2 August 2005, when the proportion of Archaea ranged from 2.1 to $2.8 \%$ of TDC (Fig. 4e). 

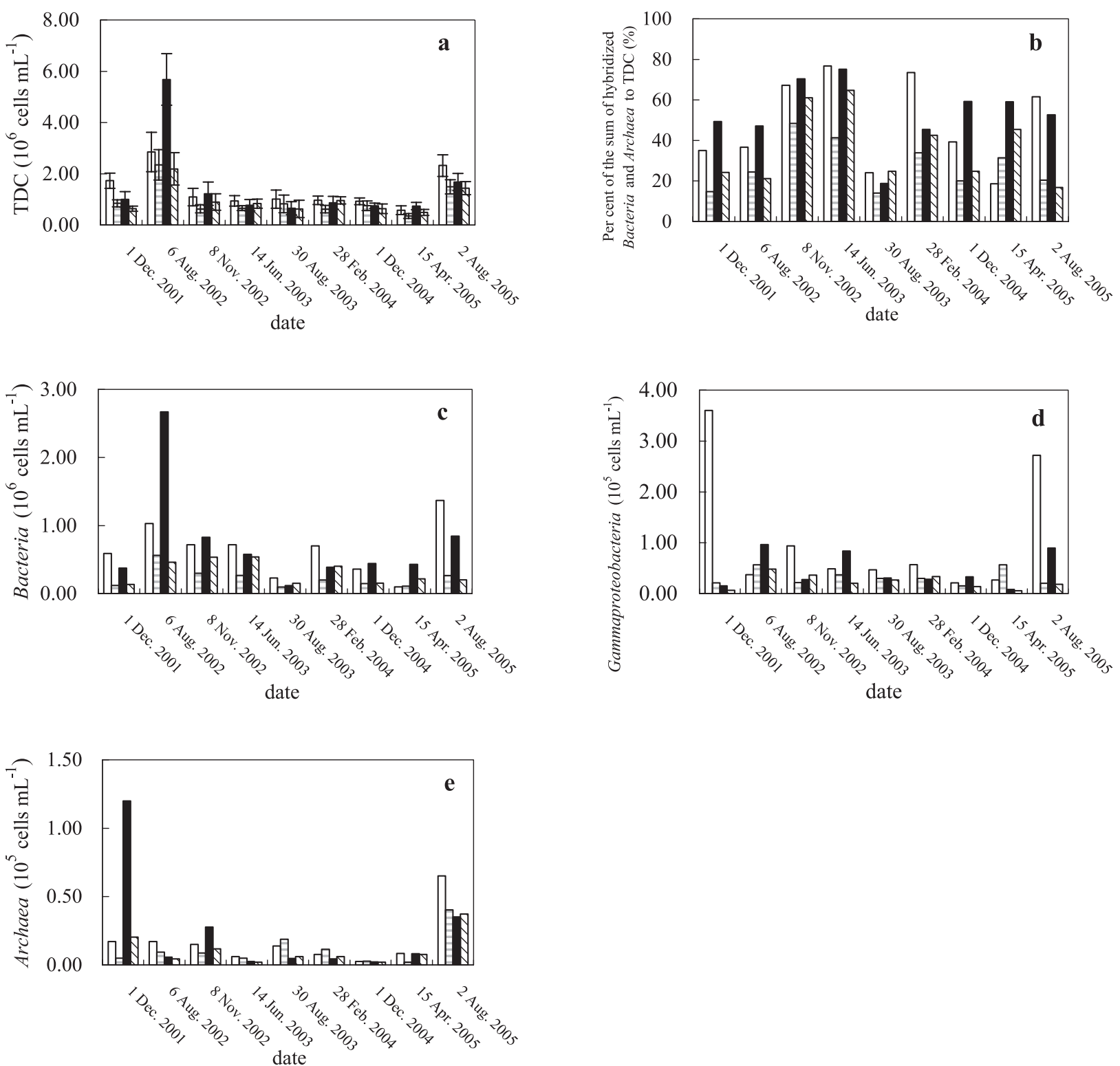

Fig. 4. Changes in bacterial abundance. a, Total bacterial count; $\mathbf{b}$, sum of hybridized Bacteria and Archaea as a percentage of TDC; $\mathbf{c}$, Bacteria;

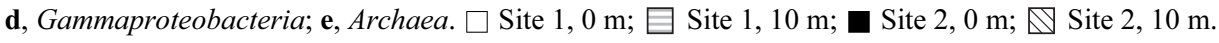

Although the densities of Bacteria $\left(9.75 \times 10^{4}\right.$ to $2.29 \times 10^{5}$ cells $\mathrm{mL}^{-1}, 11.8-23.8 \%$ of TDC) and Gammaproteobacteria $\left(2.68 \times 10^{4}\right.$ to $4.70 \times 10^{4}$ cells $\mathrm{mL}^{-1}, 3.6-4.7 \%$ of TDC) were very low on 30 August 2003, the density of Archaea was not extremely low $\left(4.85 \times 10^{3}\right.$ to $1.88 \times 10^{4}$ cells $\mathrm{mL}^{-1}, 0.7-$ $2.3 \%$ of TDC). On 1 December 2004, the number of Archaea observed was very low compared with other samples. Neither the number nor the proportion of Archaea showed seasonal fluctuation.

\section{Discussion}

In the studied area, the number of bacteria decreased in the order TDC, Bacteria, Gammaproteobacteria, and Archaea. The proportion of Bacteria found in this study ranged from 11.8 to $76.1 \%$ of TDC, with a mean of $40 \%$, which is within the range found in Chesapeake Bay²). However, this was lower than values reported for the Baltic Sea $^{12)}$, the German Bight ${ }^{9)}$, surface waters of coastal California $^{5)}$, and the Delaware Estuary ${ }^{17)}$. These studies did not describe the environmental conditions, thus it is difficult 

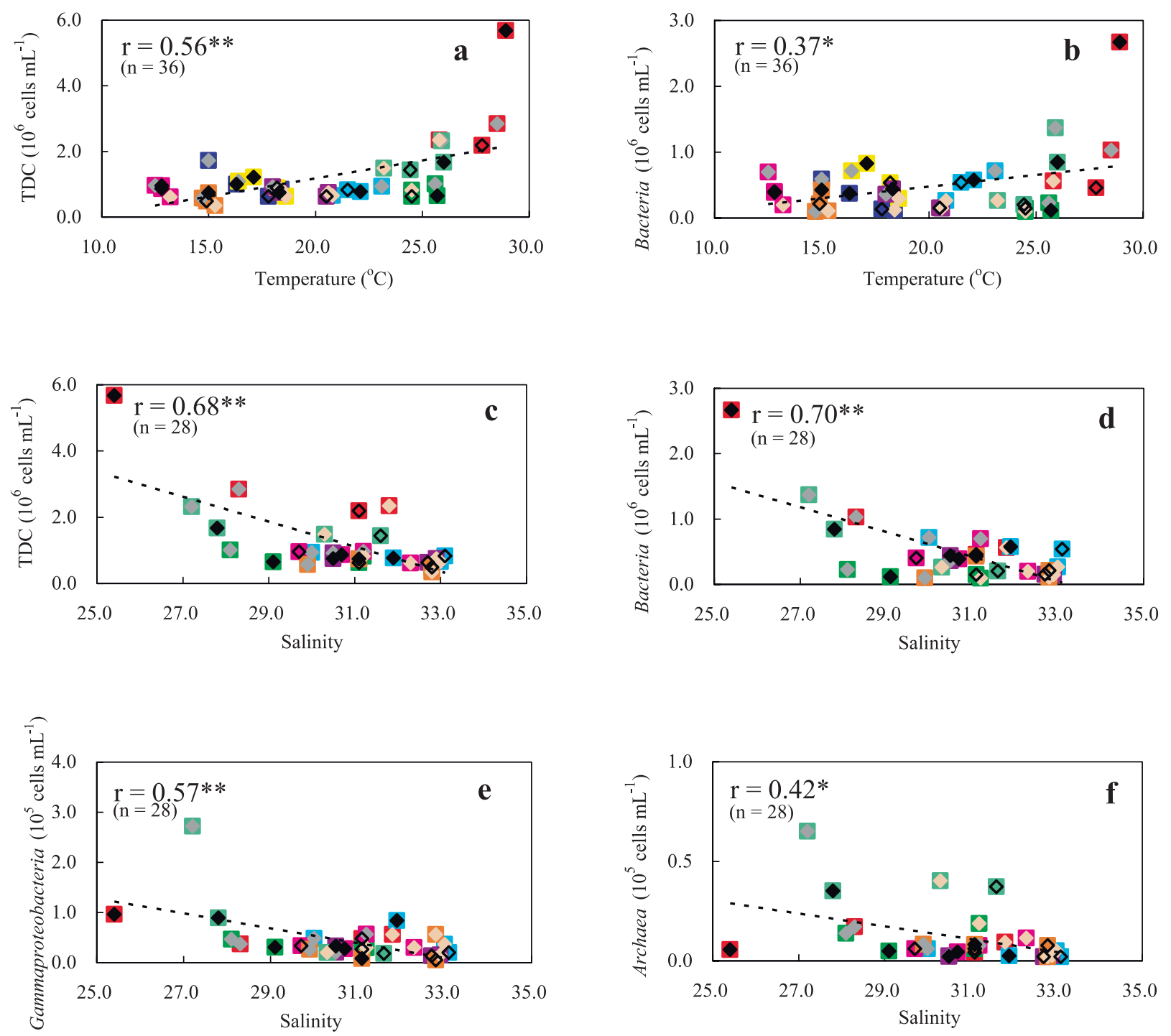

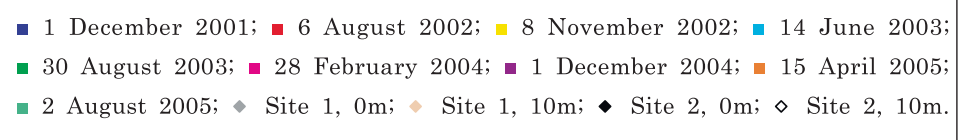

Fig. 5. Relation between temperature, salinity, and bacterial abundance. a, relation between temperature and TDC; $\mathbf{b}$, relation between temperature and Bacteria; $\mathbf{c}$, relation between salinity and TDC; $\mathbf{d}$, relation between salinity and Bacteria; e, relation between salinity and Gammaproteobacteria; f, relation between salinity and Archaea; ${ }^{* *} p<0.01 ;{ }^{*} p<0.05$.

to explain the differences in these estimates. One reason may be differences in the methods employed. Since nearshore samples, in particular, contained abundant particles, we employed criteria to exclude very tiny cells and cell-like particles with low fluorescence in order to differentiate target cells clearly from non-bacterial particles in FISH.

Archaea contributed to only $0.1-3.0 \%$ of TDC in our study, which is similar to the percentage found in Chesa- peake Bay²).

When we analyzed the relationship between environmental parameters and bacterial abundance, temperature showed a positive relation with TDC ( $p<0.01$, Fig. 5a) and Bacteria $(p<0.05$, Fig. 5b). Horizontal studies conducted in the Delaware Estuary using FISH found a good relationship between temperature and the abundance of Bacteria ${ }^{17)}$. They also showed a good relation between temperature and leucine 

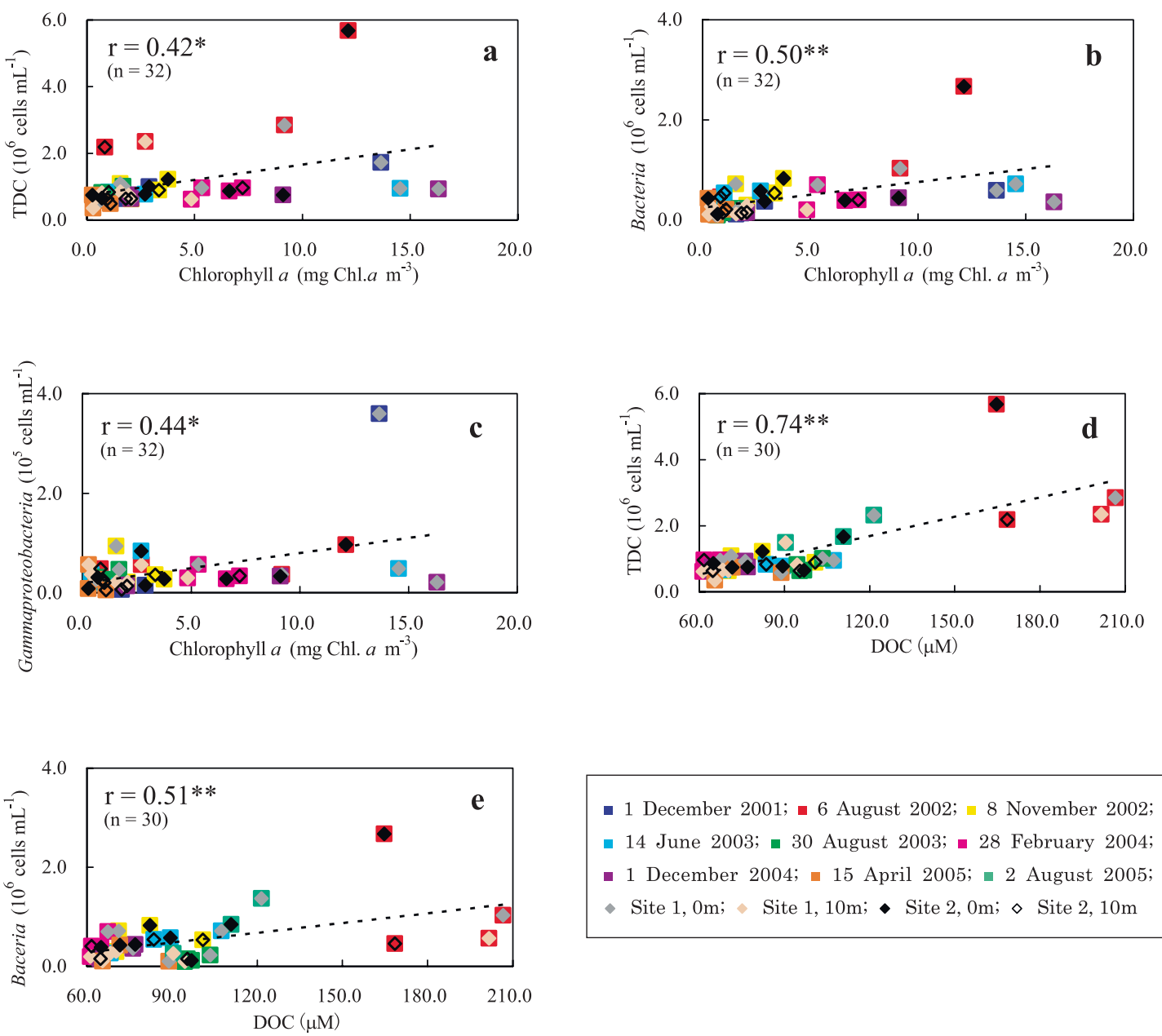

- 1 December 2001; 6 August 2002; 8 November 2002;

- 14 June 2003; - 30 August 2003; - 28 February 2004;

- 1 December 2004; - 15 April 2005; - 2 August 2005;

Site $1,0 \mathrm{~m} ; \quad$ Site $1,10 \mathrm{~m} ; \bullet$ Site $2,0 \mathrm{~m} ; \diamond$ Site $2,10 \mathrm{~m}$

Fig. 6. Relation between chlorophyll $a$, DOC, and bacterial abundance. a, relation between chlorophyll $a$ and TDC; b, relation between chlorophyll $a$ and Bacteria; $\mathbf{c}$, relation between chlorophyll $a$ and Gammaproteobacteria; d, relation between DOC and TDC; e, relation between DOC and Bacteria; ** $p<0.01 ; * p<0.05$.

incorporation. Thus, temperature may directly govern bacterial activity, resulting in high abundance; however, the balance between growth and grazing loss needs to be considered carefully. In our study, a negative relationship with salinity was found for all bacterial groups analyzed: TDC $(p<0.01$, Fig. 5c), Bacteria ( $p<0.01$, Fig. 5d), Gammaproteobacteria ( $p<0.01$, Fig. 5e), and Archaea ( $p<0.05$, Fig. 5f). Troussellier et al. ${ }^{31)}$ also showed that the abundance of bacteria decreased with increasing salinity in a study conducted along an estuarine gradient in the Mediterranean Sea. Because we found a negative relation between the abundance of Gammaproteobacteria and salinity, and relatively low salinity was observed in surface water (Fig. 2b), we surmised that the abundance of Gammaproteobacteria was influenced by discharged river water either directly or indirectly. Understanding of the environmental control of the abundance of Archaea is still limited, particularly for coastal waters ${ }^{23)}$. The relation between salinity and the abundance of Archaea needs detailed analysis with respect to genetic composition and whether a comparison can be made with marine archaeal profiles ${ }^{21}$.

The abundance of phytoplankton, represented by chlorophyll $a$, displayed a clearer relation with the number of Bacteria ( $p<0.01$, Fig. $6 \mathrm{~b})$ and somewhat less of a relation with TDC and the number of Gammaproteobacteria $(p<0.05$, Fig. $6 \mathrm{a}$ and $6 \mathrm{c})$. The possibility of controlling bacterial abundance by using phytoplankton biomass has long been suggested and recently it was experimentally elucidated by Horner-Devine et al. ${ }^{14)}$. Furthermore, TDC and the number of Bacteria related strongly with DOC $(p<0.01$, Fig. $6 \mathrm{~d}$ and $6 \mathrm{e})$. DOC is known to be a key factor that drives bacterial activity and abundance ${ }^{16,24)}$. 
Measurements of salinity suggested that the freshwater discharge directly affected the surface water chemistry at Site 1, being located inside the Shimizu Port and surrounded completely by factories and domestic buildings, but the influence did not seem to reach a depth of $10 \mathrm{~m}$ at this site. The freshwater discharge containing a large amount of DOC (about $200 \mu \mathrm{M}$ ) led to a $10-60 \%$ higher concentration of DOC in surface water at Site 1 compared with the other sampling points.

Furthermore, it was suggested that the freshwater supplied a large amount of nutrients to Site 1. High concentrations of nutrients were also observed at the surface at Site 1 compared with the other sampling points. Nutrient concentrations there were 1 - to 40 -fold higher than at $10 \mathrm{~m}$ depth at Site 2, particularly (Fig. 2).

Relations between environmental parameters and bacteria, thus, provide us an overview of planktonic bacterial abundance in a coastal area being influenced by freshwater supply through a river. Bacterial abundance was influenced by differences in temperature, though this effect did not appear in archaeal abundance. Phytoplankton was another regulator of bacterial abundance.

The interesting relation between temperature and bacterial abundance, which appeared clearly in samples from a depth of $10 \mathrm{~m}$ at Site 1, where salinity did not change much (Fig. 2b) and bacterial abundance (except Archaea) related well with DOC, may suggest that increasing temperature accompanying eutrophication will lead to high bacterial abundance and probably a change in bacterial community structure. The importance of temperature as a constraint on marine bacterial communities may increase with the continuance of the greenhouse effect.

Another exciting finding concerns Archaea and their environmental control. Whether a negative relation between salinity and the abundance of Archaea can be explained by the supply of freshwater is uncertain, at least until information is available on the genetic constituents of Archaea in comparison with those at upstream locations.

\section{Acknowledgements}

We thank Prof. Yoshimi Suzuki and Dr. Rumi Sohrin at Shizuoka University of Science for measuring the concentrations of DOC, nutrients, and chlorophyll $a$. We also thank Mr. Yoshio Hori, Miho Marina Co. Ltd., for his assistance in sampling. This work was supported by a grant-in-aid for Scientific Research from the Japan Society for the Promotion of Science (JSPS) (No. 16310024).

\section{References}

1) Amann, R.I., B.J. Binder, R.J. Olson, S.W. Chisholm, R. Devereux, and D.A. Stahl. 1990. Combination of 16S rRNAtargeted oligonucleotide probes with flow cytometry for analyzing mixed microbial populations. Appl. Environ. Microbiol. 56:1919-1925.

2) Bouvier, T.C., and P.A. del Giorgio. 2002. Compositional changes in free-living bacterial communities along a salinity gradient in two temperate estuaries. Limnol. Oceanogr. 47:453-470.

3) Brosius, J., T.J. Dull, D.D. Sleeter, and H.F. Noller. 1981. Gene organization and primary structure of a ribosomal RNA operon from Escherichia coli. J. Mol. Biol. 148:107-127.

4) Casamayor, E.O., C. Pedrós-Alió, G. Muyzer, and R. Amann. 2002. Microheterogeneity in $16 \mathrm{~S}$ ribosomal DNA-defined bacterial populations from a stratified planktonic environment is related to temporal changes and to ecological adaptations. Appl. Environ. Microbiol. 68:1706-1714.

5) Cottrell, M.T., and D.L. Kirchman. 2000. Community composition of marine bacterioplankton determined by $16 \mathrm{~S}$ rRNA gene clone libraries and fluorescence in situ hybridization. Appl. Environ. Microbiol. 66:5116-5122.

6) DeLong, E.F., G.S. Wickham, and N.R. Pace. 1989. Phylogenetic stains: ribosomal RNA-based probes for the identification of single cells. Science. 243:1360-1363.

7) DeLong, E.F., D.G. Franks, and A.L. Alldredge. 1993. Phylogenetic diversity of aggregate-attached vs. free-living marine bacterial assemblages. Limnol. Oceanogr. 38:924-934.

8) Eilers, H., J. Pernthaler, and R. Amann. 2000. Succession of pelagic marine bacteria during enrichment: a close look at cultivation-induced shifts. Appl. Environ. Microbiol. 66:4634-4640.

9) Eilers, H., J. Pernthaler, J. Peplies, F.O. Glöckner, G. Gerdts, and R. Amann. 2001. Isolation of novel pelagic bacteria from the German Bight and their seasonal contributions to surface picoplankton. Appl. Environ. Microbial. 67:5134-5142.

10) Ferguson, R.L., E.N. Buckley, and A.V. Palumbo. 1984. Response of marine bacterioplankton to differential filtration and confinement. Appl. Environ. Microbiol. 47:49-55.

11) Fuchs, B.M., M.V. Zubkov, K. Sahm, P.H. Burkill, and R. Amann. 2000. Changes in community composition during dilution cultures of marine bacterioplankton as assessed by flow cytometric and molecular biological techniques. Environ. Microbiol. 2:191-201.

12) Glöckner, F.O., B.M. Fuchs, and R. Amann. 1999. Bacterioplankton compositions of lakes and oceans: a first comparison based on fluorescence in situ hybridization. Appl. Environ. Microbiol. 65:3721-3726.

13) González, J.M., and M.A. Moran. 1997. Numerical dominance of a group of marine bacteria in the $\alpha$-subclass of the class Proteobacteria in coastal seawater. Appl. Environ. Microbiol. 63:42374242.

14) Horner-Devine, M.C., M.A. Leibold, V.H. Smith, and B.J.M. Bohannan. 2003. Bacterial diversity patterns along a gradient of primary productivity. Ecol. Lett. 6:613-622.

15) Kaku, N., A. Ueki, K. Ueki, and K. Watanabe. 2005. Methanogenesis as an important terminal electron accepting process in estuarine sediment at the mouth of Orikasa river. Microbes Environ. 20:41-52.

16) Kato, K. 1984. Heterotrophic activity, substrate active bacteria and specific Vmax for DOC. Arch. Hydrobiol. Beih. Ergebn. 
Limnol. 19:7-13.

17) Kirchman, D.L., A.I. Dittel, R.R. Malmstrom, and M.T. Cottrell. 2005. Biogeography of major bacterial groups in the Delaware Estuary. Limnol. Oceanogr. 50:1697-1706.

18) Kondo, R., K.J. Purdy, S.Q. Silva, and D.B. Nedwell. 2007. Spatial dynamics of sulphate-reducing bacterial compositions in sediment along a salinity gradient in a UK estuary. Microbes Environ. 22:11-19.

19) Langenheder, S., E.S. Lindström, and L.J. Tranvik. 2005. Weak coupling between community composition and functioning of aquatic bacteria. Limnol. Oceanogr. 50:957-967.

20) Manz, W., R. Amann, W. Ludwig, M. Wagner, and K.-H. Schleifer. 1992. Phylogenetic oligodeoxynucleotide probes for the major subclasses of Proteobacteria: problems and solutions. Syst. Appl. Microbiol. 15:593-600.

21) Massana, R., E.F. DeLong, and C. Pedrós-Alió. 2000. A few cosmopolitan phylotypes dominate planktonic archaeal assemblages in widely different oceanic provinces. Appl. Environ. Microbiol. 66:1777-1787.

22) Murphy, J., and J.P. Riley. 1962. A modified single solution method for the determination of phosphate in natural waters. Anal. Chim. Acta. 27:31-36.

23) Murray, A.E., C.M. Preston, R. Massana, L.T. Taylor, A. Blakis, K. Wu, and E.F. DeLong. 1998. Seasonal and spatial variability of bacterial and archaeal assemblages in the coastal waters near Anvers Island, Antarctica. Appl. Environ. Microbiol. 64:25852595.

24) Nagata, T. 2000. Production mechanisms of dissolved organic matter, p. 121-152. In D.L. Kirchman (ed.), Microbial ecology of the oceans. John Wiley \& Sons, New York.

25) Nishimura, Y., C. Kim, and T. Nagata. 2005. Vertical and sea- sonal variations of bacterioplankton subgroups with different nucleic acid contents: possible regulation by phosphorus. Appl. Environ. Microbiol. 71:5828-5836.

26) Pinhassi, J., and T. Berman. 2003. Differential growth response of colony-forming $\alpha$ - and $\gamma$-proteobacteria in dilution culture and nutrient addition experiments from Lake Kinneret (Israel), the Eastern Mediterranean Sea, and the Gulf of Eilat. Appl. Environ. Microbiol. 69:199-211.

27) Porter, K.G., and Y.S. Feig. 1980. The use of DAPI for identifying and counting aquatic microflora. Limnol. Oceanogr. 25:943948.

28) SCOR-UNESCO. 1966. Determination of photosynthetic pigments in seawater, p. 11-18. In Monographs on Oceanographics Methodology 1. UNESCO, Paris, France.

29) Solórzano, L. 1969. Determination of ammonia in natural waters by the phenolhypochlorite method. Limnol. Oceanogr. 14:799801.

30) Stahl, D.A., and R. Amann. 1991. Development and application of nucleic acid probes, p. 205-248. In E. Stackebrandt and M. Goodfellow (ed.), Nucleic acid techniques in bacterial systematics. John Wiley and Sons, Chichester, England.

31) Troussellier, M., H. Schäfer, N. Batailler, L. Bernard, C. Courties, P. Lebaron, G. Muyzer, P. Servais, and J. Vives-Rego. 2002. Bacterial activity and genetic richness along an estuarine gradient (Rhone River plume, France). Aquat. Microb. Ecol. 28:13-24.

32) Wallner, G., R. Amann, and W. Beisker. 1993. Optimizing fluorescent in situ hybridization with rRNA-targeted oligonucleotide probes for flow cytometric identification of microorganisms. Cytometry. 14:136-143. 